University of Nebraska - Lincoln

DigitalCommons@University of Nebraska - Lincoln

Paleolimnology and Paleoclimate Studies in Upper Klamath Lake, Oregon

Steven M. Colman

US Geological Survey, 384 Woods Hole Rd., Woods Hole, MA 02543, USA

J. Platt Bradbury

5784 Horseradish Gulch, Golden, C0 80403, USA

Joseph G. Rosenbaum

US Geological Survey, MS 980, Box 25046, Denver Federal Center, Denver, CO 80225, USA

Follow this and additional works at: https://digitalcommons.unl.edu/usgsstaffpub

Part of the Earth Sciences Commons

Colman, Steven M.; Bradbury, J. Platt; and Rosenbaum, Joseph G., "Paleolimnology and Paleoclimate Studies in Upper Klamath Lake, Oregon" (2004). USGS Staff -- Published Research. 280.

https://digitalcommons.unl.edu/usgsstaffpub/280

This Article is brought to you for free and open access by the US Geological Survey at DigitalCommons@University of Nebraska - Lincoln. It has been accepted for inclusion in USGS Staff -- Published Research by an authorized administrator of DigitalCommons@University of Nebraska - Lincoln. 
This article is a U.S. government work, and is not subject to copyright in the United States.

\title{
Paleolimnology and paleoclimate studies in Upper Klamath Lake, Oregon ${ }^{\star}$
}

\author{
Steven M. Colman ${ }^{1, *}$, J. Platt Bradbury ${ }^{2}$ and Joseph G. Rosenbaum ${ }^{3}$ \\ ${ }^{1}$ US Geological Survey, 384 Woods Hole Rd., Woods Hole, MA 02543, USA; ${ }^{2} 5784$ Horseradish Gulch, \\ Golden, CO 80403, USA; ${ }^{3}$ US Geological Survey, MS 980, Box 25046, Denver Federal Center, Denver, \\ CO 80225, USA; *Author for correspondence (e-mail: scolman@usgs.gov)
}

Received 8 October 2002; accepted in revised form 2 July 2003

Key words: Climate proxies, Lake sediments, Paleoclimate, Paleolimnology, Upper Klamath Lake

\begin{abstract}
The subsiding Upper Klamath Lake Basin contains sediments that were continuously deposited in a shallow, freshwater lake for more than 40000 years. Well dated by radiometric methods and containing volcanic ashes of known age, these sediments constitute a valuable paleoclimate record. Sediment constituents and properties that reflect past climatic conditions in the area include pollen, diatoms, sediment geochemistry, and sediment magnetic properties. Many of these proxy measurements are also useful for comparing natural conditions in the lake to conditions following human settlement. Because of its location, the paleoclimate record from Upper Klamath Lake is valuable for comparisons to offshore marine records and as part of latitudinal transects of paleoclimate records along the west coast of the Americas.
\end{abstract}

\section{Introduction}

Upper Klamath Lake is one of the largest freshwater lakes in the western United States. Its size, shallow depth, and location in an actively subsiding basin clearly give it the potential to provide a long, high-resolution sedimentary record of past limnological and climatic conditions, on a variety of timescales.

The lake recently has been the center of considerable controversy, especially in the dry water year of 2001, because it is a source of irrigation water, the home of endangered fish species, and the source of commercially harvested algae. Competition among these uses, together with Native American

\footnotetext{
$\star$ This is the first in a series of eight papers published in this special issue, resulting from paleoenvironmental studies in the Upper Klamath Lake Basin. These studies were conducted by the US Geological Survey and its collaborators as part of a paleoclimate research effort called the Correlation of Marine and Terrestrial Records Project. Steven M. Colman served as guest editor of this special issue.
}

water and fishing rights, have generated significant resource-management difficulties (Boyd et al. 2002).

Paleoclimate studies in the Upper Klamath Lake Basin were begun by the US Geological Survey and its collaborators in the early 1990s as part of an effort called the Correlation of Marine and Terrestrial Records Project (Adam et al. 1995). The overall purpose of this project was to characterize the last 130000 years of alternating cooling and warming periods in global climate, by comparing records from both marine and terrestrial sites along the west coast of the United States. Much of the character of terrestrial climate in the western US is governed by the position and duration of centers of atmospheric circulation over the north Pacific Ocean and adjacent western North America. Paleolimnological and paleoclimate records in southern Oregon and southern California, dated by radiocarbon, can be linked to study the interaction of these climate systems and their effects on terrestrial ecosystems. Upper Klamath Lake is especially relevant in this regard, 


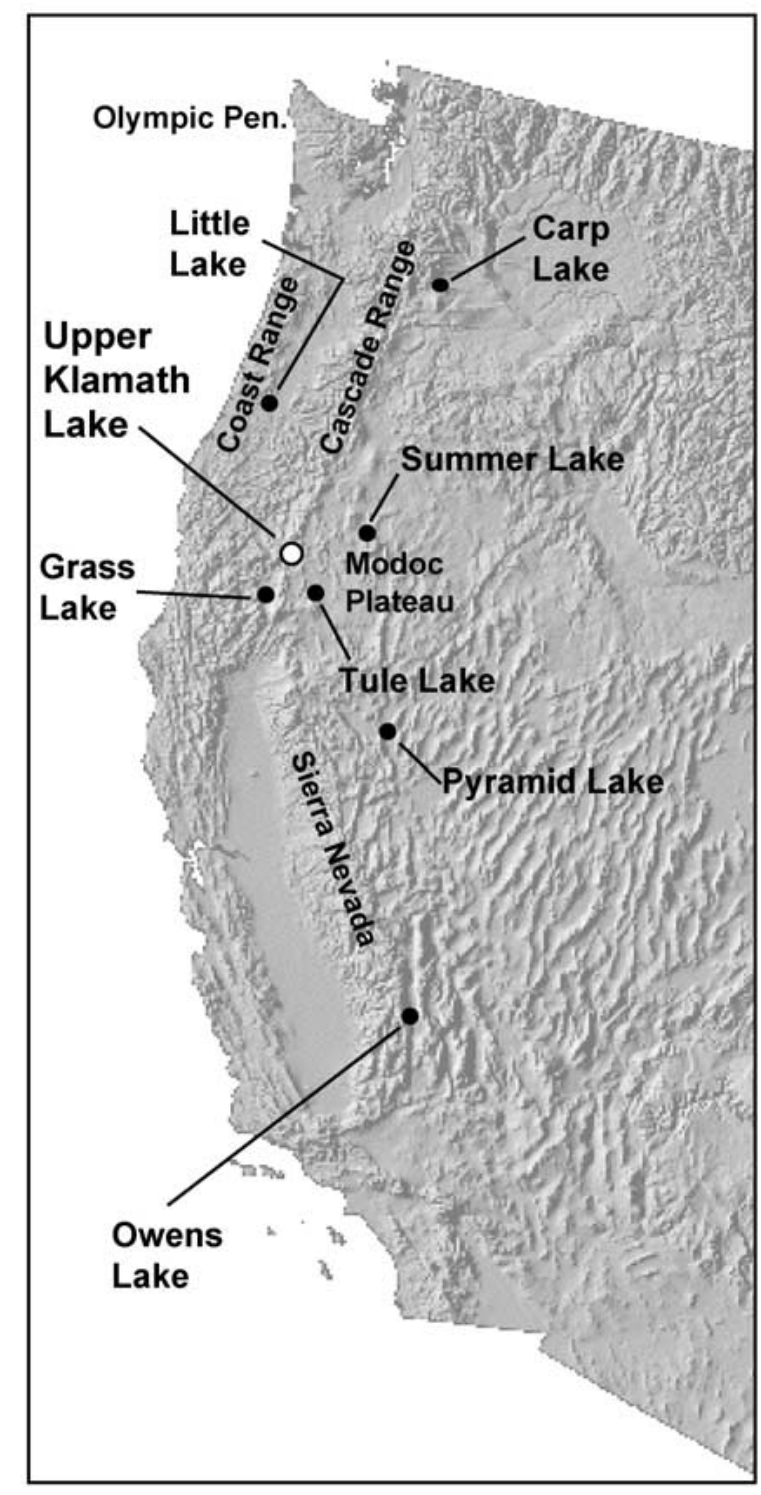

Figure 1. Shaded relief map of the western United States, showing the locations of Upper Klamath Lake and other sites discussed in this issue.

because it lies at the latitude that witnesses the seasonal interplay of the Aleutian Low and the Subtropical High that control regional precipitation and the strength and persistence of the California Current upwelling system offshore to the west.

Other terrestrial sites studied as part of the overall effort included (Figure 1) Carp Lake (Whitlock and Bartlein 1997), in south-central Washington; a variety of tectonic basins in northern California and southern Oregon, including Tule Lake and the Upper Klamath Basin; and Owens Lake, in southeastern California (Smith et al. 1997). This report focuses on Upper Klamath Lake, along with some additional data from Grass Lake, California.

The sediment sequences in various basins were first sampled by taking cores with a rotary drill rig, supplemented later by other kinds of cores. For technical reasons, rotary drilling was done on fringing marshes of lakes or in sediment-filled basins. One of the best sites was located on the edge of Caledonia Marsh (Figure 2), adjacent to Upper Klamath Lake. Because of artesian conditions in the initial rotary drill hole, the site was later cored with a Livingstone square-rod piston corer.

Initial descriptions and analyses of the Livingstone core from Caledonia Marsh (see Cores and Sediments section) indicated that beneath an upper section of marsh sediments, the rest of the core was comprised of diatomaceous sediment deposited in an open lake. In 1996, piston and gravity cores were taken in the open-water part of the present lake in order to obtain lake sediments of the same age as the sediments in the upper part of the Caledonia Marsh core. Together, these cores provide a continuous lakesediment record extending back more than 40000 years.

In addition to the continuous paleoclimate record archived in the cored sediments, the composite sequence of lacustrine sediment allows a comparison among modern, recently past, and ancient limnological conditions, as well as an assessment of human impacts on the lake.

\section{Setting}

\section{Geological setting}

Upper Klamath Lake occupies the eponymous basin between the southern Cascades and the Basin and Range near the western margin of the Modoc Plateau (MacDonald 1966) (Figure 1). The area is dominated by basalt flows and continental sedimentary rocks in graben-like structures produced by NNW-trending normal faults (McKee et al. 1983) (Figure 2). Grabens and lava flows have 


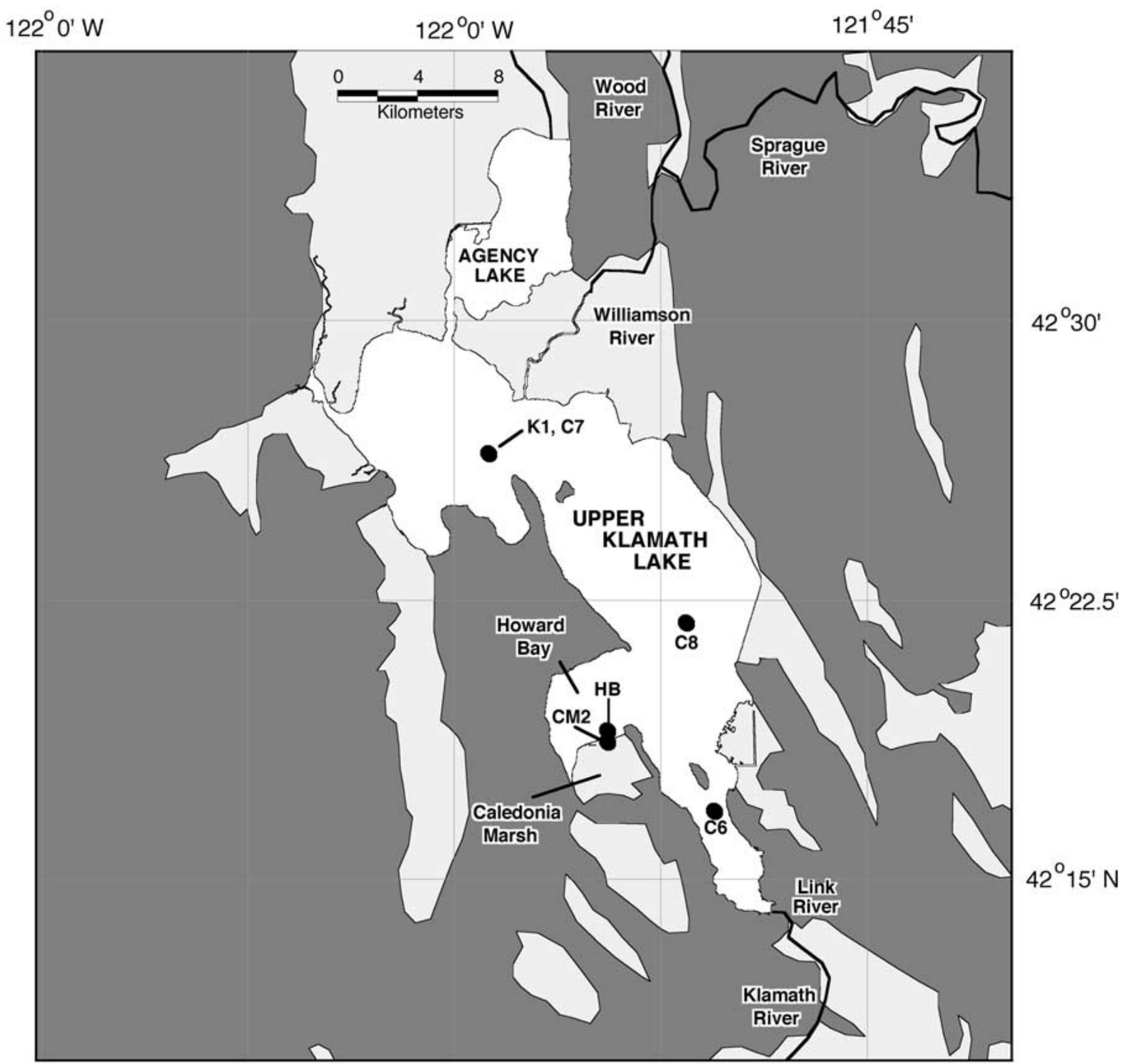

Figure 2. Map of Upper Klamath Lake showing locations of cores discussed in this issue. Light gray indicates alluvial, marsh, and lacustrine deposits; dark gray indicates volcanic bedrock.

controlled the development of large lakes, such as Upper Klamath Lake and Tule Lake, just north and south of the Oregon-California border, respectively. The Klamath graben is thought to extend into the Cascade Range, where its northern end is marked by Mount Mazama and the Crater Lake caldera (Bacon et al. 1999). During the late Tertiary, the Klamath basin may have drained south into the ancestral Pit River. Drainage was probably interrupted by early growth of the
Medicine Lake volcanic field sometime in the late Pliocene or early Pleistocene (Donnelly-Nolan and Nolan 1986). Since then, Upper Klamath Lake has emptied into the Klamath River, flowing to the south and west.

At Tule Lake, at least $550 \mathrm{~m}$ of lake sediment was deposited, a record that appears to extend back to the Miocene (Rieck et al. 1992). The total thickness of sedimentary fill in Upper Klamath Lake is unknown, but unconsolidated sediments 
have been probed to depths of 20-30 m (Sanville et al. 1974). Outcrops of diatomite surrounding Upper Klamath Lake suggest that the total lacustrine fill is much thicker. Because the Klamath Basin is just east of the Cascades, numerous volcanic ashes, some suitable for tephrochronology, occur in outcrop and in cores of lacustrine sediments of this area (Sarna-Wojcicki et al. 1991).

Upper Klamath Lake and the downstream basins in northern California remain tectonically active today. The Klamath basin is marked by numerous young fault scarps, some of which displace late Pleistocene deposits (Hawkins et al. 1989) or are fresh enough to suggest that they have been active within the last $10 \mathrm{ka}$ (Sherrod 1993). No late Holocene fault scarps have been described in the Klamath Lakes Valley, and historical seismicity in the area is low (Hawkins et al. 1989; Wiley et al. 1993). However, seismic studies of the sediment fill of Upper Klamath Lake document progressive down-faulting of the Mazama tephra $(7.5 \mathrm{cal} \mathrm{ka})$ as the graben continues to deepen (Colman et al. 2000). In 1993, two earthquakes, both with sizes of $\mathrm{Mw} 6.0$, occurred about $20 \mathrm{~km}$ northwest of Klamath Falls, separated by a few hours, resulting in widespread damage and two deaths (Sherrod 1993). Ground cracking and landslides were reported, but no surface fault displacement related to the earthquakes was observed (Wiley et al. 1993).

\section{Climate setting}

Upper Klamath Lake lies in a semi-arid climate with hot, dry summers and moderately cold, wet winters. Mean annual precipitation (1961-1990) is $34.3 \mathrm{~cm}$. Although summer thunderstorms occasionally occur, approximately $70 \%$ of the precipitation occurs as snow between the months of October and March (Figure 3). Precipitation is highly variable both locally and interannually. El Niño years tend to have greater than average precipitation. Snowfall averages as much as $89 \mathrm{~cm}$ per year (Snyder and Morace 1997). Annual maximum and minimum temperatures average 16.1 and $1.7^{\circ} \mathrm{C}$, respectively. Prevailing winds, ranging between 8 and $>24 \mathrm{~km} / \mathrm{h}$, are south to west-southwest during the wet season and northerly at other times (Hazel 1969).

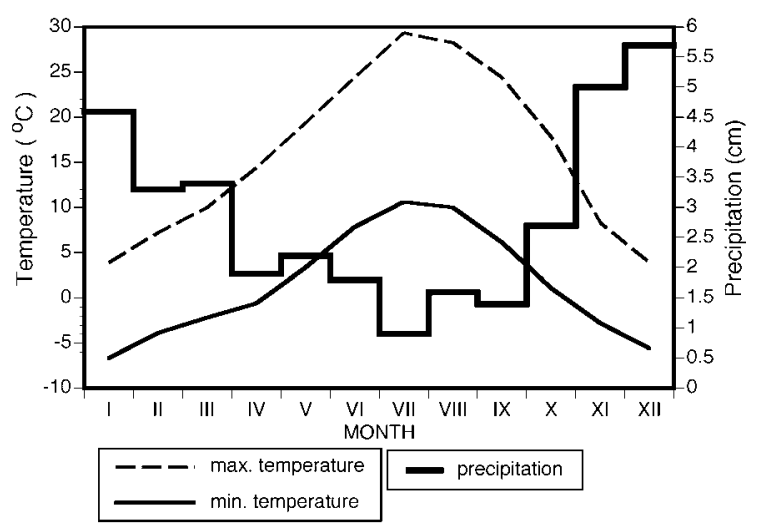

Figure 3. Average monthly air temperatures and precipitation at Klamath Falls, Oregon, 1961-1990. Data from World Weatherdisk.

\section{Limnological setting}

Upper Klamath Lake (elevation $1263 \mathrm{~m}$ ) remains the largest and highest lake in the Klamath basin system, having an area of 31000 ha and a mean depth of about $2.5 \mathrm{~m}$ (Sanville et al. 1974). The maximum depth of Upper Klamath Lake $(15 \mathrm{~m})$ lies in a restricted trough along the southwest margin of the lake next to a fault scarp, which suggests that tectonism may play a local role in controlling lake depth. The Wood, Williamson, and Sprague Rivers feed Upper Klamath Lake from the north and the lake is drained by the Klamath River to the south and west (Figure 2).

Upper Klamath Lake is fresh (ca. $100 \mu \mathrm{S} / \mathrm{cm}$ ) and slightly alkaline; major ion chemistry is dominated by $\mathrm{Na}^{+}, \mathrm{Ca}^{2+}$, and $\mathrm{HCO}_{3}^{-}$ions, and dissolved silica concentrations often exceed $10 \mathrm{mg} / \mathrm{l}$. The $\mathrm{pH}$ ranges between 7 (spring) and 10 (summer). Nitrogen and phosphorus concentrations vary considerably (Figure 4) but can be quite high and are believed to largely reflect agricultural drainage (Miller and Tasch 1967; Snyder and Morace 1997). Hydrochemical determinations for the spring, summer and fall of 1982 (Table 1) are typical and within the ranges of values of longer data series (Bradbury 1991). Marsh environments have constant, neutral or slightly lower $\mathrm{pH}$ values (Bond et al. 1968), presumably due to decomposing vascular plant material. The Williamson and Sprague Rivers are hydrochemically similar to each other and to Upper Klamath Lake. 

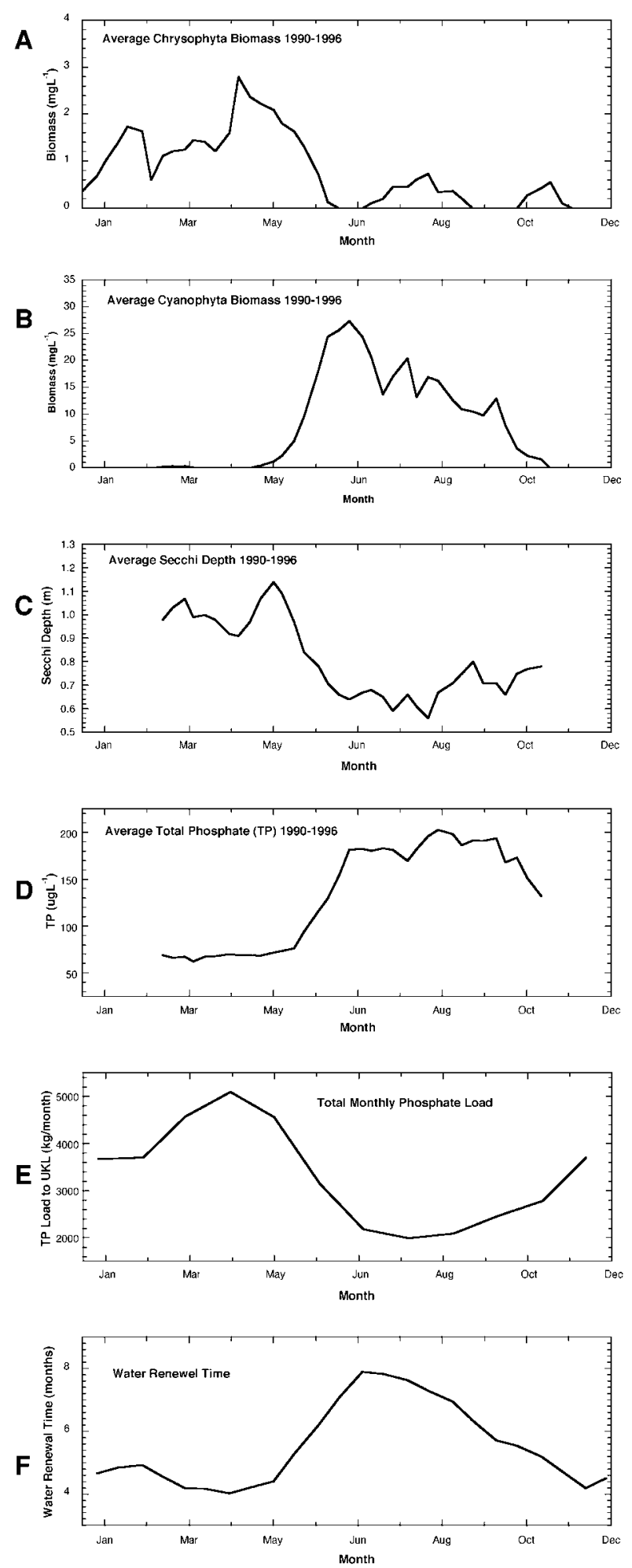

Figure 4. Modern limnological measurements from Upper Klamath Lake. (A-D) Data from Kann (1997). (E, F) Data from Gearheart et al. (1995). 
Table 1. Water chemistry data for Upper Klamath Lake, from Johnson et al. (1985).

\begin{tabular}{lccc}
\hline & May, 1982 & August, 1982 & November, 1982 \\
\hline $\mathrm{Na}^{+}$ & 7.6 & 8.3 & 9.6 \\
$\mathrm{~K}^{+}$ & 2.0 & 2.0 & 2.1 \\
$\mathrm{Ca}^{2+}$ & 6.5 & 3.5 & 8.0 \\
$\mathrm{Mg}^{2+}$ & 3.8 & 3.5 & 4.1 \\
$\mathrm{Cl}^{-}$ & 2.0 & 2.7 & 5.1 \\
$\mathrm{SO}_{4}^{2-}$ & 6.7 & 1.7 & 3.5 \\
Alkalinity & 36 & 46 & 49 \\
Conductivity & 96 & 100 & 115 \\
Total P & 0.079 & 0.184 & 0.162 \\
\hline
\end{tabular}

Values in $\mathrm{mg} / \mathrm{l}$, conductivity in $\mu \mathrm{S} / \mathrm{cm}$.

Upper Klamath Lake freezes at least intermittently in January and February during most winters and mixes more or less continuously during the open water season. Wind speeds as low as $7 \mathrm{~km} / \mathrm{h}$ are sufficient to resuspend bottom sediment. Massive resuspension 'events' occur when winds of $18 \mathrm{~km} / \mathrm{h}$ blow down the long axis of the lake (Laenen and LeTourneau 1996). Nutrients regenerated from bottom sediments disturbed by mixing may be important nutrient sources for phytoplankton (Miller and Tasch 1967; Bortleson and Fretwell 1993). Lake transparency is low in the summer (Secchi disk values typically less than $1 \mathrm{~m}$ ) when large cyanobacterial blooms form (Figure 3a-c). Because of mixing, the water mass is usually oxygenated, although the biochemical oxygen demand of the sediments is high and episodic low oxygen levels contribute to ecological stress and mortality of native fish (Kann 1997).

Today, blooms of cyanobacteria (bluegreen algae, mostly Aphanizomenon flos-aquae) occur in Upper Klamath Lake (Figure 4), presumably at least in part due to increased nutrient loading from agricultural utilization of drained lake-margin marshland and recycling of nutrients from the lake bottom (Sanville et al. 1974; Snyder and Morace 1997). This cyanobacterium fixes nitrogen and can control buoyancy to remain in the upper water column where favorable illumination conditions exist. It dominates in summer months when Upper Klamath Lake usually stratifies for short periods of time.

\section{Cores and sediments}

CM2, the longest core $(12.8 \mathrm{~m})$, was taken with a modified Livingstone piston corer in Caledonia
Marsh, a shallow, Scirpus-filled embayment at the southern edge of Howard Bay on the southwestern margin of Upper Klamath Lake (Figure 2). A road berm constructed in 1916 (Snyder and Morace 1997) separates Caledonia Marsh from Howard Bay. Before then, the marsh graded into the shallow, open-water lacustrine environments of Howard Bay. A short, 169-cm piston core (HB) was taken from Howard Bay, in about $1 \mathrm{~m}$ water depth and $400 \mathrm{~m}$ north of the Caledonia Marsh core site (Figure 2) to provide a correlative, openwater sediment section for the upper part of the Caledonia Marsh core that was disturbed by road berm construction. To investigate the character of limnological change in the main, open-water part of Upper Klamath Lake, a third, 9-m piston core (K1) was extracted from the northern basin of Upper Klamath Lake (Figure 2). These long cores were supplemented by short, Glew-type gravity cores aimed at recovering the sediment-water interface and the uppermost soft sediment beneath the lake in several locations. Core locations and ancillary data are in Table 2.

Core $\mathrm{K} 1$ and most of the Holocene part of core $\mathrm{CM} 2$ are characterized by diatomaceous oozes deposited in open lake environments, along with minor amounts of less diatomaceous mud and volcanic ash. The lower, glacial part of core CM2 is mostly terrigenous mud with moderate amounts of diatoms, whereas the upper part grades into marsh deposits similar to those forming at the site today. Core HB and the gravity cores contain only diatomaceous oozes.

\section{Discussion}

The foundation of any paleoclimate record is the chronological framework for deposition of the sediments. Colman et al. (2004 - this issue) provide an array of radiocarbon ages, tephrochronology data, and ${ }^{210} \mathrm{~Pb}-{ }^{137} \mathrm{Cs}$ analyses that, taken together, make the UKL sediments one of the better dated paleoclimate records in the western United States. Because of resuspension and mixing of the bottom sediments, the ${ }^{210} \mathrm{~Pb}-{ }^{137} \mathrm{Cs}$ data provide only generalized rates of sedimentation for the last century or so, but these data are useful for constraining recent limnological changes. Radiocarbon analyses provide a reliable and 
Table 2. Summary of cores discussed in this issue.

\begin{tabular}{lllllr}
\hline Core & Type & $\begin{array}{l}\text { Latitude } \\
\left({ }^{\circ} \mathrm{N}\right)\end{array}$ & $\begin{array}{l}\text { Longitude } \\
\left({ }^{\circ} \mathrm{W}\right)\end{array}$ & $\begin{array}{l}\text { Water depth } \\
(\mathrm{m})\end{array}$ & $\begin{array}{l}\text { Length }^{\mathrm{a}} \\
(\mathrm{cm})\end{array}$ \\
\hline CM2 & Livingstone & 42.3112 & 121.9070 & 0 & 1290 \\
HB & Livingstone & 42.3163 & 121.9070 & 1.5 & 155 \\
K1 & Livingstone & 42.4402 & 120.0209 & 2.5 & 910 \\
C7 & Gravity & 42.4402 & 120.0209 & 2.5 & 46 \\
C6 & Gravity & 42.2802 & 120.1575 & 2.3 & 41 \\
C8 & Gravity & 42.3645 & 120.1402 & 2.4 & 61 \\
\hline
\end{tabular}

${ }^{\mathrm{a}}$ Length of Livingstone cores corrected for compaction during extrusion.

continuous chronology from a few hundred to more than 20000 years ago. Identification of volcanic ashes from eruptions of known age bolster the radiocarbon chronology and demonstrate that the continuous sedimentary record extends back to more than 40000 years ago.

Upper Klamath Lake is currently hypereutrophic, and mid-19th century European settler's reports suggest that it was at least eutrophic in its undisturbed state. However, the amount of change caused by human activities, such as draining of surrounding marshes, upstream agriculture, forestry, and grazing activities, and other development activities, is controversial. Our continuous lacustrine record allows assessment of such limnological changes. Bradbury et al. (2004a - this issue) suggest that both diatoms and remains of bluegreen algae mark progressive eutrophication of the lake in the 20th century, especially after about 1920. At the same time, changes in magnetic properties of the sediments and the occurrence of reworked volcanic ash seem to reflect drainage and ditching of marshes surrounding the lake. These conclusions are compatible with a parallel study of recent limnological changes by (Eilers et al. in press).

Diatoms are a key indicator of past limnological conditions on both long and short time scales. Bradbury et al. (2004b - this issue) explore the diatom record of changes in the basin over the past 40000 years, in combination with lithological and geochemical evidence. The data suggest that the last glacial maximum was characterized by shallow water conditions in a cold, windy environment. Prior to the glacial maximum, temperaturesensitive diatom assemblages suggest millennial scale fluctuations in climate, similar to, but in some cases out of phase with, fluctuations observed in other western US lakes. Post-glacial changes included a transition to warmer, higher-productivity diatom assemblages and a mid-Holocene interval of lower lake level and lake-floor anoxia.

The generalized pollen profile for Upper Klamath Lake is supplemented by detailed pollen and lithological analyses from nearby Grass Lake (Figure 1). Hakala and Adam (2004 - this issue) focus on the pollen record of Grass Lake for the period $19000-36000$ years ago, and compare it to the generalized record in Upper Klamath Lake (Bradbury et al. 2004b - this issue). Variations in the percentages of conifer and sagebrush pollen recorded changes in vegetation (steppe, open pine forest, dense pine forest) that reflect changes in precipitation. Relatively dry conditions (especially during the glacial maximum) were interrupted by century to millennial-scale intervals of increased precipitation. In addition to pollen evidence for precipitation changes, major fluctuations in sand concentration in the Grass Lake core appear to reflect temperature shifts and the proximity to upper tree line. The record suggests three periods of intense cold, during two of which Grass Lake was above upper treeline.

The magnetic properties of sediments are powerful tools being developed for paleoenvironmental reconstruction; for this reason, our group spent considerable effort examining the magnetic properties of Upper Klamath basin sediments. In the first of a pair of papers, Reynolds et al. (2004 - this issue) compare sediment magnetic properties with other petrological and textural properties of the lacustrine sediments from this volcanic terrain. They argue that the terrigenous fractions of the sediments are mixtures of highly magnetic, glacially generated detritus (glacial flour) and less magnetic, more weathered detritus derived from 
unglaciated parts of the catchment. The finer grained, highly magnetic sediments contain a high proportion of planktic diatoms indicative of cold, oligotrophic limnic conditions. Variations in the magnetic indicators of glacial flour indicate a glacial history compatible with other evidence for glaciation in the basin.

Rosenbaum and Reynolds (2004a - this issue) extend the relationship between glacial flour and sediment magnetic properties to develop a quantitative measure of the flux of glacial flour into Upper Klamath Lake, and they use this measure as an indication of degree of glaciation of the basin. The results suggest a low extent of glaciation with millennial-scale fluctuations until about 25000 years ago, followed by extensive glaciation from about 25000 to about 16000 years ago. A thousand-year maximum in glaciation occurred, centered on about 18500 years ago. About 16000 years ago, the extent of glaciers abruptly decreased, and after 14000 years ago, no discernible glacier flour was deposited in Upper Klamath Lake sediments.

As part of an effort to better understand the magnetic properties of the non-glacial component of Upper Klamath Lake sediments, Rosenbaum and Reynolds (2004b - this issue) studied stream sediments and soils from the lake drainage basin. Weathering progressively destroys titanomagnetite, which is abundant in fresh volcanic rocks, thereby diminishing the quantity of titanomagnetite both absolutely and relative to hematite. Hydrodynamic sorting during stream transport may also produce differences in sediment magnetic properties, which cannot be completely separated from the effects of weathering. Together, weathering and sorting combine to produce the magnetic properties of the non-glacial lithic component of Upper Klamath Lake sediments, which together with glacial flour and biogenic components, make up the sediments as a whole.

\section{Conclusions}

Taken together, the data and inferences presented in this volume provide a detailed history of climate and limnological change in the Upper Klamath Lake Basin. This history is well dated and resolves sub-millennial climate events, including glacial advances. Particularly during the last glacial maximum and the events leading to it (Oxygen Isotope Stages 2 and 3), the data show millennial-scale fluctuations in climate, vegetation, limnology, and glacial activity, until about $21 \mathrm{cal}$ ka. Diatom and pollen evidence suggest that maximum glacial conditions occurred about $21 \mathrm{ka}$, but that cold, dry, windy conditions persisted until about $15 \mathrm{ka}$. The rock-flour record of glacial activity is consistent with the paleoclimate indicators, and suggests that maximum glacial activity in the basin occurred between 18 and $19 \mathrm{ka}$.

Our studies, especially those involving sediment dating, diatom productivity, and the magnetic properties of sediments, supply information on many of the processes that are involved in the delivery of sediment to the lake floor. The results also provide a comparison between natural conditions in Upper Klamath Lake and current, anthropogenically disturbed conditions, and show that the lake has been significantly impacted by human activities.

The findings contained in the papers in this volume have important implications for comparisons between lacustrine records in the western United States and marine records from the eastern Pacific Ocean (e.g., Gardner et al. 1997; Herbert et al. 2001). The Upper Klamath Lake record is also a contribution toward transects that document latitudinal variations in climate along the west coast of the Americas (e.g., Markgraf 1995; Bradbury et al. 2001).

\section{Acknowledgements}

We thank David Adams for his initial leadership of the Klamath Lakes Drilling Project, and Jacob Kann for his help with our later operations on Upper Klamath Lake. The many other people who provided collaboration, technical assistance, and analytical resources for our studies of Upper Klamath Lake are too numerous to list here, but many are acknowledged in the individual papers in this volume. Helpful reviews of this paper were provided by John Crusius and Jeff Donnelly. Our work on Upper Klamath Lake was supported by the Earth Surface Dynamics (formerly Global Change and Climate History) Program of the US Geological Survey. 


\section{References}

Adam D.P., Bradbury J.P., Dean W.E., G. J.V. and SarnaWojcicki A.M. 1995. US Geological Survey Open-File Report 95-34. 92 pp.

Bacon C.R., Lanphere M.A. and Champion D.E. 1999. Late Quaternary slip rate and seismic hazards of the West Klamath Lake Fault zone near Crater Lake, Oregon Cascades. Geology 27: 43-46.

Bond C.E., Hazel C.R. and Vincent D. 1968. Relations of nuisance algae to fishes in Upper Klamath Lake. Terminal Report to FWPCA, Dept. of Fisheries and Wildlife, Oregon State University, $119 \mathrm{pp}$.

Bortleson G.C. and Fretwell M.O. 1993. A review of possible causes of nutrient enrichment and decline of endangered sucker populations in Upper Klamath Lake, Oregon. US Geological Survey Water Resources Investigations Report 93-4087, $24 \mathrm{pp}$.

Boyd M., Kirk S., Wiltsey M. and Kasper B. 2002. Upper Klamath Lake Drainage Total Maximum Daily Load (TMDL) and Water Quality Management Plan (WQMP). Oregon Department of Environmental Quality, Portland, Oregon, $188 \mathrm{pp}$.

Bradbury J.P. 1991. The late Cenozoic diatom stratigraphy of Tule Lake, Siskiyou County, California. J. Paleolimnol. 6: 205-255.

Bradbury J.P., Colman S.M. and Reynolds R.L. 2004a. The history of recent limnologic changes and human impact on Upper Klamath Lake, Oregon. J. Paleolim. 31: 151-165 (this issue)

Bradbury J.P., Colman S.M. and Dean W.E. 2004b. Limnological and climatic environments at Upper Klamath Lake, Oregon during the past 45,000 years. J. Paleolim. 31: 167-188 (this issue).

Bradbury J.P., Grosjean M., Stine S. and Sylvestre F. 2001. Full and late glacial lake records along the PEP 1 transect: Their role in developing interhemispheric paleoclimate interactions. In: Markgraf V. (ed.), Interhemispheric Climate Linkages, Academic Press, New York, pp. 265-291.

Colman S.M., Bradbury J.P., McGeehin J.P., Holmes C.W., Edginton D. and Sarna-Wojcicki A.M. 2004. Chronology of sediment deposition in Upper Klamath Lake, Oregon. J. Paleolim. 31: 139-149 (this issue).

Colman S.M., Rosenbaum J.G., Reynolds R.L. and SarnaWojcicki A.M. 2000. Post-Mazama (7 KA) faulting beneath Upper Klamath Lake, Oregon. Bull. Seismol. Soc. Am. 90: 243-247.

Donnelly-Nolan J.M. and Nolan K.N. 1986. Catastrophic flooding and eruption of ash-flow tuff at Medicine Lake volcano, California. Geology 14: 875-878.

Eilers J.M., Kann J., Cornett J., Moser K., St. Armand A. and Gubala C.P. (in press). Recent Paleolimnology of Upper Klamath Lake, Oregon. Hydrobiologia.

Gardner J.W., Dean W.E. and Dartmell P. 1997. Biogenic sedimentation beneath the California current system for the past $30 \mathrm{kyr}$ and its paleoceanographic significance. Paleoceanography 12: 207-225.

Gearheart R.A., Anderson J.K., George-Forbes M., Osburn M. and Oros D. 1995. Watershed strategies for improving water quality in Upper Klamath Lake, Oregon. Vol. 1, Humboldt State University, California, 41 pp.

Hakala K.J. and Adam D.P. 2004. Late Pleistocene vegetation and climate in the southern Cascade Range and the Modoc Plateau region. J. Paleolim. 31: 189-215 (this issue).

Hawkins F.F., Foley L.L. and LaForge R.C. 1989 Seismotectonic study for the Fish Lake and Fourmile Lake dams, Rogue River Project, Oregon. US Bureau of Reclamation, Seismotectonic Report 89-3, 26 pp.

Hazel C.R. 1969. Limnology of Upper Klamath Lake, Oregon, with emphasis on benthos. Ph.D. Dissertation, Oregon State University, Corvallis, $184 \mathrm{pp}$.

Herbert T.D., Schuffert J.D., Andreasen D., Heusser L., Lyle M., Mix A., Ravelo A.C., Stott L.D. and Herguera J.C. 2001. Collapse of the California current during Glacial Maxima linked to climate change on land. Science 293: 71-76.

Johnson D.M., Petersen R.R., Lycan D.R., Sweet J.W., Neuhaus M.E. and Schaedel A.L. 1985. Atlas of Oregon Lakes. Oregon State University Press, Corvallis, Oregon, $317 \mathrm{pp}$.

Kann J. 1997. Ecology and water quality dynamics of a shallow hypereutrophic lake dominated by cyanobacteria (Aphanizomenon flos-aque). PhD dissertation, University of North Carolina, Chapel Hill, North Carolina, 110 pp.

Laenen A. and LeTourneau A.P. 1996. Upper Klamath Lake nutrient loading study - Estimate of wind-induced resuspension of bed sediment during periods of low lake elevation. US Geological Survey Open-File Report 95-414, 11 pp.

MacDonald G.A. 1966. Geology of the Cascade Range and Modoc Plateau. In: Bailey E.H. (ed.), Geology of Northern California, California Division of Mines and Geology Bulletin 190, pp. 65-96.

Markgraf V. 1995. PEP I: The Americas transect. In: Bradley R.S., Dodson J., Dulpessy J.-C., Gasse F., Liu T.S. and Markgraf V. (eds), Paleoclimates of the Northern and Southern Hemispheres: The PANASH Project - The PoleEquator-Pole Transects, PAGES Publication Series 95-1, Bern, Switzerland, pp. 23-41.

McKee E.H., Duffield W.A. and Stern R.J. 1983. Late Miocene and early Pliocene basaltic rocks and their implication for crustal structure, northeastern California and south-central Oregon. Geol. Soc. Am. Bull. 94: 292-304.

Miller W.E. and Tasch J.C. 1967. Interim Report, Upper Klamath Lake Studies, Oregon. Federal Water Pollution Control Administration, $37 \mathrm{pp}$.

Reynolds R.L., Rosenbaum J.G., Rapp J., Kerwin M.W., Bradbury J.P., Colman S.M. and Adam D.P. 2004. Record of Late Pleistocene glaciation and deglaciation in the southern Cascade Range: I. Petrologic evidence from lacustrine sediment in Upper Klamath Lake, southern Oregon. J. Paleolim. 31: 217-233 (this issue).

Rieck H.J., Sarna-Wojcicki A.M., Meyer C.M. and Adam D.P. 1992. Magnetostratigraphy and tephrochronology of an upper Pliocene to Holocene record in lake sediments at Tulelake, northern California. Geol. Soc. Am. Bull. 104: 409-428.

Rosenbaum J.G. and Reynolds R.L. 2004a. Record of Late Pleistocene glaciation and deglaciation in the southern Cascade Range: II. Flux of glacial flour in a sediment core from Upper Klamath Lake. J. Paleolim. 31: 235-252 (this issue). 
Rosenbaum J.G. and Reynolds R.L. 2004b. Basis for paleoenvironmental interpretation of magnetic properties of sediment from Upper Klamath Lake (Oregon): Effects of weathering and minerological sorting. J. Paleolim. 31: 253-265 (this issue).

Sanville W.D., Powers C.F. and Gahler A.R. 1974. Sediments and sediment-water nutrient interchange in Upper Klamath Lake, Oregon. US Environmental Protection Agency Report EPA-660/3-74-015, 45 pp.

Sarna-Wojcicki A.M., Lajoie K.R., Meyer C.E., Adam D.P. and Reick H.J. 1991. Tephrochronologic correlation of upper Neogene sediments along the Pacific margin, conterminous United States. In: Morrison R.B. (ed.), Quaternary NonGlacial Geology: Conterminous United States. Geological Society of America, Decade of North American Geology, Vol. K-2: Boulder, Colorado, pp. 117-140.

Sherrod D.R. 1993. Historic and prehistoric earthquakes near Klamath Falls, Oregon. Earthquakes Volcanoes 24: 106-120.

Smith G.I., Bischoff J.L. and Bradbury J.P. 1997. Synthesis of the paleoclimate record from Owens Lake core OL-92.
In: Smith G.I. and Bischoff J.L. (eds), An 800,000-Year Paleoclimate Record from Core OL-92, Owens Lake, Southeast California. Geological Society of America, Special Paper 317, pp. 143-160.

Snyder D.T. and Morace J.L. 1997. Nitrogen and phosphorus loading from drained wetlands adjacent to Upper Klamath and Agency Lakes, Oregon. US Geological Survey Water-Resources Investigations Report 97-4059, $67 \mathrm{pp}$.

Whitlock C. and Bartlein P.J. 1997. Vegetation and climate change in northwest America during the past $125 \mathrm{kyr}$. Nature 388: 57-61.

Wiley T.J., Sherrod D.R., Keefer D.K., Qamar A., Shuster R.L., Dewey J.W., Mabey M.A., Black G.L. and Wells R.E. 1993. Klamath Falls earthquakes, September 20, 1993 - including the strongest quake ever measured in Oregon. Oregon Geol. 55: $127-134$. 